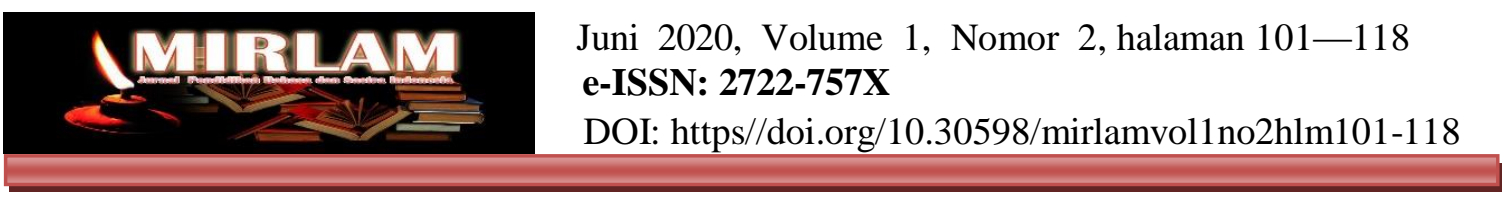

\title{
PENINGKATAN KEMAMPUAN MENULIS KARANGAN ARGUMENTASI DENGAN MENGGUNAKAN MODEL THINK TALK WRITE (TTW) SISWA KELAS X IPA SMA PERTIWI AMBON
}

\author{
Florida Carolina Renwarin \\ Heppy Leunard Lelapary \\ Elsa Latupeirissa \\ Email :floridarenwarin@gmail.com
}

\begin{abstract}
ABSTRAK: Penelitian ini merupakan penelitian tindakan kelas (PTK) dengan data yang dijaring dari kegiatan menulis karangan argumentasi. Berdasarkan hasil analisis dapat disimpulkan bahwa penggunaaan model Think Talk Write (TTW) dapat meningkatkan kemampuan menulis karangan argumentasi siswa. Hasil penelitian ini menjelaskan bahwa $85 \%$ siswa mengalami peningkatan dalam menulis karangan argumentasi atau memenuhi KKM dengan jumlah nilai yang diperoleh siswa secara keseluruhan 78,81. Dengan demikian, penggunaan model TTW membuat pembelajaran menjadi menarik, menyenangkan, dan memberi kemudahan bagi siswa untuk berkreasi dan menciptakan ide-ide yang dituangkan dalam sebuah karangan argumentasi yang baik.
\end{abstract}

Kata kunci: kemampuan menulis, karangan argumentasi, Model TTW 


\title{
IMPROVING WRITING ABILITY OF ARGUMENTATION REQUIREMENTS USING THE THINK TALK WRITE (TTW) MODEL CLASS IPA X PERTIWI HIGH SCHOOL AMBON
}

\author{
Florida Carolina Renwarin \\ Heppy Leunard Lelapary \\ Elsa Latupeirissa \\ Email : floridarenwarin@gmail.com
}

\begin{abstract}
This research is a classroom action research (PTK) with data captured from arguments writing activities. Based on the results of analysis it can be concluded that the use of a Think Talk Write (TTW) model can improve ability to write essays on students arguments. The results of this study explain that $85 \%$ of students experienced an increase in writing essay arguments or fulfilling KKM with the total score abtained by students as a whole 78,81 . Thus, the use of the TTW model makes learning interesting, fun, and makes it easy for student to create and create ideas as outlined in a good essay.
\end{abstract}

Key word: writing ability, essay argumentation, TTW Model. 


\section{A. PENDAHULUAN}

Undang-Undang Sistem Pendidikan RI Nomor 20 tahun 2003 bertujuan bahwa semua peserta didik diharapkan menjadi manusia beriman dan bertakwa terhadap Tuhan Yang Maha Esa, berakhlak mulia, sehat, berilmu, cakap, kreatif, mandiri, dan menjadi warga negara yang demokratif serta bertanggung jawab. Untuk mewujudkan tujuan pendidikan itu, di sekolah perlu dilaksanakan pembelajaran yang komprehensif. Siswa diharapkan untuk bisa cakap, kreatif, dan mandiri dalam proses pembelajaran.

Dalam pelajaran Bahasa Indonesia siswa diharuskan untuk terampil dalam berbahasa. Keterampilan berbahasa yang dimaksudkan, yaitu menyimak, berbicara, membaca, dan menulis. Keempat keterampilan tersebut harus dimiliki siswa secara seimbang dan merata, karena keterampilan yang satu dengan keterampilan yang lainnya saling terkait dan menunjang.

Menulis pada dasarnya adalah proses untuk mengemukakan ide atau gagasan dalam bahasa tulis. Akhadiah dalam Abidin (2012:181) memandang menulis sebagai sebuah proses, yaitu proses penuangan gagasan atau ide ke dalam bahasa tulis yang dalam praktiknya proses menulis diwujudkan dalam beberapa tahapan yang merupakan satu sistem yang utuh.

Tarigan (1982:22) juga mengemukakan bahwa menulis ialah menurunkan atau melukiskan lambang-lambang grafik yang menggambarkan suatu bahasa yang 
dipahami oleh seseorang, sehingga orang-orang lain dapat membaca lambanglambang grafik tersebut kalau mereka memahami bahasa dan gambaran grafik itu.

Menulis merupakan keterampilan akhir yang harus dimiliki siswa setelah menyimak, berbicara, dan membaca. Oleh karena itu, menulis sering dianggap keterampilan yang paling sukar. Saat menulis, seseorang akan memanfaatkan keterampilan berbahasa yang lain, yaitu menyimak dan membaca. Dalam menulis sebuah gagasan, ide, dan pikiran, seseorang akan mengolah informasi yang diperolehnya dari proses menyimak atau proses membaca sehingga menjadi sebuah informasi dalam bentuk tulisan atau karangan. Tulisan yang baik dan sistematis adalah tulisan yang disusun menggunakan bahasa yang baik dan benar, pilihan kata, struktur sintaksis, dan gaya bahasa yang tepat.

Tulisan atau karangan terbagi menjadi lima jenis, yaitu narasi, eksposisi, deskripsi, persuasi, dan argumentasi. Argumentasi adalah tulisan yang bertujuan meyakinkan atau membujuk pembaca tentang kebenaran pendapat penulis. Pembelajaran menulis karangan argumentasi bertujuan agar siswa terampil dalam menuangkan ide dan pendapatnya disertai fakta sebagai bukti pendukung sehingga pendapatnya dapat diterima serta mempengaruhi pembaca.

Berdasarkan hasil penelitian yang dilakukan peneliti pada siswa kelas X IPA SMA Pertiwi Ambon ditemukan fakta bahwa menulis menjadi suatu hal yang kurang diminati dan kurang mendapat respon yang baik dari siswa. Mereka menganggap 
remeh pembelajaran menulis. Menurut mereka, menulis merupakan kegiatan yang mudah dilakukan sehingga tidak memerlukan tingkat perhatian dan konsentrasi lebih.Namun ketika siswa dihadapkan dengan persoalan yang berhubungan dengan kegiatan menulis siswa tampak mengalami kesulitan dalam menulis, baik penguasaan ejaan, tanda baca, kosa kata, pilihan kata maupun cara penyusunan kalimat dengan struktur penulisan yang efektif. Kesulitan tersebut menyebabkan mereka tidak mampu menyampaikan pikiran dan gagasan dengan baik sehingga siswa enggan untuk menulis.Selain itu, siswa juga masih sulit membedakan antara karangan argumentasi dengan jenis karangan yang lain, seperti karangan narasi, deskripsi, eksposisi, dan persuasi.

Siswa kurang mampu mengemukakan fakta-fakta, antara opini dan fakta kadang disamakan. Ini juga merupakan salah satu dari sekian alasan mengapa menulis karangan argumentasi sangat sulit dilakukan oleh siswa kelas X IPA SMA Pertiwi Ambon.Model pembelajaran yang digunakan guru juga kurang variatif sehingga siswa merasa jenuh dalam mengikuti mata pelajaran Bahasa Indonesia.

Permasalahan-permasalahan tersebut harus disikapi dengan usaha untuk mengatasinya.Salah satunya adalah dengan menerapkan model pembelajaran yang tepat dalam pembelajaran menulis, dalam hal ini difokuskan pada pembelajaran menulis karangan argumentasi. 
Salah satu model pembelajaran untuk meningkatkan kemampuan siswa dalam menulis karangan argumentasi adalah model Think Talk Write (TTW). Model pembelajaran think talk write adalah model pembelajaran yang mendorong siswa untuk berpikir, berbicara, dan kemudian menulis berkenaan dengan satu topik. Penerapan model pembelajaran ini diharapkan dapat membekali siswa dengan pengetahuan awal tentang karangan argumentasi dengan baik.

Model pembelajaran ini memperkenankan siswa untuk mengkonstruksi pengetahuannya sendiri sehingga pemahaman konsep siswa menjadi lebih baik, bisa mengkomunikasikan atau mendiskusikan pemikirannya dengan temannya sehingga saling membantu dan saling bertukar pikiran, dan juga melatih siswa untuk menuliskan hasil diskusinya ke bentuk tulisan secara sistematis sehingga siswa akan lebih memahami materi dan membantu siswa untuk mengkomunikasikan ide-idenya dalam bentuk tulisan. Dengan model pembelajaran ini pula akan membekali siswa tentang cara menulis dengan struktur penulisan yang efektif sehingga kebiasaan yang salah dalam proses menulis karangan argumentasi dapat dikurangi.

Penelitian ini bertujuan untuk meningkatkan kemampuan menulis karangan argumentasi dengan menggunakan model think talk write siswa kelas X IPA SMA Pertiwi Ambon. 


\section{B. METODE PENELITIAN}

Jenis penelitian ini adalah penelitian tindakan kelas (PTK). Menurut Elliot (dalam Wiriaatmadja, 2014:12) penelitian tindakan sebagai kajian dari sebuah situasi sosial dengan kemungkinan tindakan untuk memperbaiki kualitas situasi sosial tersebut. Tujuan utama penelitian ini adalah untuk mendeskripsikan kemampuan siswa dalam pembelajaran di kelas, terutama deskripsi peningkatan kemampuan siswa dalam menulis karangan argumentasi. Mampu tidaknya siswa dalam pembelajaran, hal ini sangat bergantung pada tindakan guru. Tindakan guru seperti itu bila dicatat kemudian direfleksikan kembali permasalahannya, guru tersebut dapat dikatakan pula sebagai peneliti tindakan kelas. (Aqib,dkk 2008:144).

\section{PEMBAHASAN}

Penelitian ini dilakukan berdasarkan observasi awal menulis karangan argumentasi. Dari observasi awal yang telah dilaksanakan diketahui bahwa keterampilan menulis karangan argumentasi siswa kelas X IPA SMA Pertiwi Ambon masih sangat rendah dibuktikan dengan masih banyak siswa yang belum mencapai standar KKM untuk materi karangan argumentasi, yakni 65.

Dari hasil wawancara dengan beberapa siswa diperoleh keterangan bahwa keterampilan menulis (karangan argumentasi) siswa masih kurang.mereka mengatakan bahwa mereka masih kesulitan dalam penggunaan bahasa serta penggunaan ejaan dan tanda baca. 
Peneliti juga melakukan wawancara dengan guru bahasa Indonesia. Dari hasil wawancara diperoleh keterangan bahwa guru belum pernah menggunakan model pembelajaran think talk write sebagai media pembelajaran. Guru juga menjelaskan bahwa model yang dipakai untuk menulis karangan argumentasi adalah penjelasan dan tanya jawab. Meskipun sudah memberikan penjelasan serta tanyajawab yang dilakukan oleh guru dan siswa, siswa masih kesulitan menulis karangan argumentasi. Kesulitan yang ditemukan siswa yaitu penggunaan bahasa serta penggunaan ejaan dan tanda baca. Tetapi setelah menggunakan model pembelajaran think talk write guru melihat bahwa siswa lebih memahami pelajaran khususnya menulis karangan argumentasi. Siswa begitu antusias dan tertib dalam menulis karangan argumentasi dengan menggunakan model pembelajaran think talk write. Pada pedoman observasi juga bisa dilihat bahwa setelah menggunakan model pembelajaran think talk write keaktifan siswa mulai meningkat. Awalnya hanya ada 4 orang yang aktif dalam proses belajar mengajar menjadi 17 orang yang aktif dalam proses belajar mengajar khususnya menulis karangan argumentasi.

Bertolak dari masalah yang ditemukan kemudian guru bersama penulis merencanakan tindakan yang bertujuan untuk memberikan gambaran secara jelas tentang hal-hal yang harus dilakukan di kelas untuk mengatasi masalah-masalah dalam kegiatan pembelajaran menulis karangan argumentasi. Melalui diskusi dengan guru, dicapai kesepakatan untuk menggunakan model pembelajaran yaitu model think talk write untuk kegiatan menulis karangan argumentasi. Guru menggunakan model 
think talk write untuk membuka wawasan siswa mengenai karangan argumentasi dan menugaskan siswa untuk menulis karangan argumentasi berdasarkan model pembelajaran yang digunakan.

\section{Proses Pelaksanaan Siklus I}

Proses pelaksanaaan siklus I terbagi menjadi dua kali pertemuan, masingmasing pertemuan berlangsung selama 2 × 45 menit. Secara rinci proses pelaksanaan siklus I pada tiap-tiap pertemuan sebagai berikut:

\section{a. Siklus I pertemuan ke-1}

Kegiatan PTK siklus I pertemuan ke-1 dilaksanakan pada kelas X IPA SMA Pertiwi Ambon pada tanggal 2 Maret 2018. Pembelajaran pada siklus 1 pertemuan ke-1 difokuskan pada pemahaman materi karangan argumentasi, mengenali ciri-ciri karangan argumentasi dan bagaimana cara penulisan karangan argumentasi yang benar sesuai dengan EYD.

Temuan yang dapat dilaporkan dari pelaksanaan siklus I pertemuan ke -1 adalah sebagai berikut:

\section{Hasil angket}

Berdasarkan tabel 4.1 hasil angket menulis karangan argumentasi dengan model pembelajaran think talk write siswa kelas X IPA SMA Pertiwi Ambon, dapat dijelakan ternyata selama ini guru belum pernah menggunakan model pembelajaran 
think talk write sebagai media pembelajaran.Selain itu siswa juga menyatakan bahwa sebelum menggunakan model pembelajaran think talk write mereka masih kesulitan dalam menulis karangan argumentasi.

2. Hasil penilaian diri sendiri ( Self Assessment )

Berdasarkan table 4.2 dapat diketahui hasil penilaian diri sendiri (self assessment) yang dilakukan oleh siswa kelas X IPA SMA Pertiwi Ambon dan mengikuti pembelajaran menulis karangan argumentasi dengan menggunakan model pembelajaran think talk write .

Sebanyak 14 siswa sangat termotivasi pada saat menulis karangan argumentasi dengan menggunakan model pembelajaran think talk write.

\section{b. Siklus I pertemuan ke-2}

Siklus I pertemuan ke-2 dilaksanakan pada tanggal 5 Maret 2018.Proses pelaksanan siklus I pertemuan ke-2 adalah penyampaian tujuan pembelajaran menulis karangan argumentasi dengan menggunakan model pembelajaran think talk write berlanjutan dari pertemuan pertama. Kegiatan pertama yang dilakukan siswa pada pertemuan kedua ini adalah cara menulis karangan argumentasi dengan menggunakan model pembelajaran think talk write. Kegiatan pembelajaran didahului dengan guru menuliskan pengertian karangan argumentasi serta ciri-ciri karangan argumentasi di papan tulis, setelah itu siswa mendengarkan penjelasan tentang indikator tujuan pembelajaran yang harus dicapai siswa pada menulis sebuah karangan argumentasi 
menggunakan model pembelajaran think talk write sebagai usaha untuk memotivasi siswa. Guru memberikan petunjuk tentang hal-hal yang perlu diperhatikan pada siswa waktu menulis karangan argumentasi.

Kegiatan akhir dalam pembelajaran menulis karangan argumentasi siklus I pertemuan ke-2 guru dan siswa menyimpulkan kegiatan pembelajaran serta siswa mengumpulkan hasil penulisan karangan setelah waktu yang disediakan selesai.

1. Hasil penilaian menulis karangan argumentasi

Berdasarkan table 4.3 hasil penulisan karangan argumentasi dapat dijelaskan sebagai berikut:

Penilaian menulis karangan argumentasi siswa didasarkan pada aspek penggunaan bahasa, Isi karangan, serta penggunaan ejaan dan tanda baca. Ketiga aspek tersebut dijabarkan masing-masing tiga indikator. Dengan demikian kisaran penilaian tertinggi adalah 9. Pada akhir pertemuan ke-2 siklus I setelah karangan siswa dicek, maka didapatkan hasil sebagai berikut: dari jumlah keseluruhan siswa yaitu 20, terbukti hanya 6 siswa yang nilainya memenuhi kriteria ketuntasan minimal sedangkan 14 siswa belum mencapai standar kriteria ketuntasan minimal.

Dilihat dari aspek penilaian penggunaan bahasa karangan siswa pada siklus I kurang memenuhi indikator penilaian, siswa cenderung belum bisa membedakan karangan argumntasi dengan karangan yang lain. 
Untuk aspek isi karangan, dalam menulis karangan argumentasi siswa kurang mampu dalam menggunakan kata penghubung antar kalimat, sehingga kalimat yang satu dengan yang lain tidak saling berhubungan dan juga ada beberapa kesalahan dalam penggunaan EYD pada penulisan nama tempat/lokasi dan tanda baca yang kurang tepat dalam menulis karangan argumentasi.

2. Data kesulitan siswa

Berdasarkan tabel 4.4 diketahui kesulitan yang dialami oleh siswa kelas X IPA SMA Pertiwi Ambon dalam mengikuti pembelajaran menulis karangan argumentasi dengan menggunakan model pembelajaran think talk write yaitu 14 siswa menyatakan masih merasa kesulitan dalam menulis karangan argumentasi. Apabila diklasifikasikan dari beberapa kesulitan yang dialami siswa, sebagian besar adalah dari ketiga aspek yaitu dinilai penggunaan ejaan dan tanda baca, penggunaan bahasa dan belum mampu menggunakan kata sambung yang tepat.

Dari hasil diskusi kolaborator, fakta yang diduga timbulnya masalah kesulitan siswa yaitu; siswa kurang memahami tentang ciri-ciri karangan argumentasi. Karena ada jenis-jenis karangan yang tidak mampu siswa bedakan, sehingga hanya terfokus pada pengertian sebuah karangan secara umum. 


\section{Proses Pelaksanaan Siklus II}

\section{a. Siklus II pertemuan ke-1}

Proses pelaksanaan pada siklus II pertemuan ke-1 dilakukan pada tanggal 9 Maret 2018. Proses ini dilaksanakan karena pembelajaran pada siklus 1 kurang mengatasi masalah-masalah siswa dalam menulis karangan argumentasi menggunakan model pembelajaran think talk write, sehingga pencapaian nilai yang didapat masih rendah. Mengacu pada masalah dan faktor-faktor timbulnya masalah yang ditemukan pada siklus 1, maka peneliti dan guru merancangkan untuk melakukan siklus II. Langkah dalam melakukan siklus II ini antara lain masih tetap menggunakan model think talk write tetapi pemberian materi yang dicopi dan di bagi pada setiap siswa terdapat pengertian karangan argumentasi, bagaimana ciri-ciri dari sebuah karangan argumentasi secara detail dan juga disertai dengan dua contoh karangan argumentasi, untuk mengetahui dan mengukur pemahaman siswa serta sejauh mana siswa bisa memahami materi yang diberikan oleh guru, sehingga pelaksanaan pada siklus kedua untuk memperbaiki hal-hal yang masih keliru atau salah pada siklus I.

Pada pelaksanaan siklus II ini, didasarkan pada kekurangan-kekurangan pada siklus I dan diwujudkan dalam dua kali pertemuan. Fokus pertemuan pertama pada siklus II ini yaitu menulis karangan argumentasi dengan menggunakan model pembelajaran think talk write dengan memperhatikan aspek penggunaan bahasa, isi 
karangan serta penggunaan ejaan dan tanda baca yang tepat dalam karangan. Dari analisis siklus I, sebagian besar siswa kesulitan dalam ciri-ciri karangan argumentasi tanda baca dalam proses penulisan karangan argumentasi.

Langkah selanjutnya guru menerangkan dan memberikan pertanyaan berdasarkan contoh karangan argumentasi yang ada pada lembar kerja siswa yang bertujuan untuk mengarahkan siswa untuk mengetahui bagaimana melihat dan menentukan ciri-ciri sebuah karangan argumentasi. Dari lembar kerja siswa tersebut guru mengadakan tanya jawab dan meminta siswa untuk maju kedepanmenuliskan beberapa pengertian, serta ciri-ciri sebuah karangan argumentasi. Dari jawabanjawaban siswa tersebut dapat diketahui bahwa sebenarnya siswa sudah mampu dalam menentukan sebuah karangan argumentasi dan menulisnya secara baik dalam pemilihan kata, ejaan dan tanda baca yang digunakan. Oleh karena itu, guru segera menugaskan siswa menuliskan karangan argumentasi dengan kata-kata mereka sendiri dengan topik yang sudah ditentukan. Guru kemudian mengamati keseriusan siswa dalam menulis karangan argumentasi. Setelah siswa selesai mengajarkan tugasnya dalam menulis karangan argumentasi berdasarkan contoh karangan, guru menyuruh siswa untuk segera mengumpulkan hasil kerjanya.

1. Hasil penilaian menulis karangan argumentasi

Berdasarkan tabel 4.5 kemampuan menulis karangan argumentasi siswa kelas X IPA SMA Pertiwi Ambon menunjukan adanya peningkatan yaitu pada siklus I 
pencapaian kriteria ketuntasan minimal hanya 6 siswa dengan jumlah rata-ratakelas 58,83 sedangkan pada siklus II jumlah siswa yang mencapai kriteria ketuntasan minimal meningkat yaitu 17 siswa sehingga jumlah rata-rata kelas mengalami peningkatan menjadi 78,81 . Hal ini berarti model pembelajaran yang digunakan memberikan pengaruh yang positif terhadap proses pembelajaran bahasa Indonesia khususnya menulis karangan argumentasi.

2. Data kesulitan siswa

Berdasarkan tabel 4.6 diketahi kesulitan-kesulitan yang di alami siswa kelas $\mathrm{X}$ IPA SMA Pertiwi Ambon dalam mengikuti pembelajaran menulis karangan argumentasi menggunakan model pembelajaran think talk write yaitu sebanyak 3 siswa menyatakan masih merasa kesulitan dalam menulis karangan argumentasi.Apabila diklasifikasikan dari beberapa siswa, maka sebagian besar adalah masalah penggunaan ejaan dan tandabaca.

b. Siklus II pertemuan ke-2 (refleksi)

Siklus II pertemuan ke-2 dilangsungkan pada tanggal 12 Maret 2018. Siklus II pertemuan ke-2 merupakan refleksi dari pelaksanaan penelitian tindakan kelas siklus kedua.Pertemuan kedua difokuskan untuk merevisi hasil penulisan siswa. Guru kembali mengulang pembelajaran yang difokuskan pada penulisan ejaan dan tanda baca yang salah, dan segera menyuruh siswa untuk membetulkan dengan ejaan dan tanda baca yang benar. Setelah kegiatan itu selesai guru bersama siswa melakukan 
refleksi terhadap hasil pembelajaran. Dari refleksi yang di lakukan guru dan siswa, terdapat 3 siswa yang masih merasa kesulitan dalam menulis karangan argumentasi namun jika dibandingkan dengan penelitian tindakan kelas dilaksanakan sampai siklus II maka terjadi peningkatan dimana, nilai rata-rata siswa pada siklus I penelitian tindakan kelas (PTK) hanya 58,83 dan pada pelaksanaan siklus II nilai ratarata siswa meningkat secara signifikan menjadi 78,81 .

Dari refleksi siklus II yang dilakukan dan diketahui hasil pelaksanaan penulisan karangan argumentasi dengan menggunakan model pembelajaran think talk write ternyata memberikan peningkatan terhadap hasil belajar siswa dan sangat memuaskan, maka kegiatan pembelajaran di tutuppada siklus II dengan penguatan dari guru

\section{Hasil penilaian diri sendiri (Self Assessment)}

Berdasarkan penilaian diri sendiri (self assessment) sebagaimana pada tabel 4.7 dapat diketahui bahwa sebanyak 19 siswa serius memperhatikan guru saat menerangkan, dan 19 siswa menyatakan tidak bosan menulis karangan argumentasi dengan model pembelajaran yang digunakan.

\section{Hasil angket}

Berdasarkan tabel 4.8 diketahui kesimpulan hasil angket dari pembelajaran siklus II pertemuan ke-2 yaitu 18 siswa senang belajar bahasa Indonesia, 18 siswa merasa senang apabila guru memberikan tugas menulis karangan argumentasi. 
Menurut mereka setelah model pembelajaran think talk write diterapkan sangat mempermudah mereka dalam menulis karangan argumentasi.

\section{KESIMPULAN}

Berdasarkan penyajian dan hasil dari pembahasan pada bab IV, maka peneliti dapat menarik kesimpulan antara lain: (1) penggunaan model pembelajaran think talk write siswa kelas X IPA SMA Pertiwi Ambon membuat pembelajaran menjadi menarik, menyenangkan, memberi kemudahan dan banyak manfaat bagi siswa. (2) pembelajaran dengan menggunakan model pembelajaran TTW dapat mengurangi kejenuhan dan kebosanan dalam pembelajaran menulis, dan memudahkan siswa untuk berkreasi dan menciptakan ide-ide yang dituangkan dalam sebuah karangan argumentasi yang baik.

Setelah penggunaan model pembelajaran think talk write pada siklus I nilai ratarata kelas menjadi 58,83. Pelaksanaan siklus I masih terdapat kekurangan-kekurangan antara lain siswa belum mampu membedakan karangan argumentasi dengan karangan yang lain, dan belum juga menulis karangan dengan baik sesuai EYD sehingga jumlah siswa yang memenuhi kriteria ketuntasan hanya 6 siswa dari 20 siswa. Sedangkan hasil siklus II menunjukan adanya peningkatan kemampuan siswa sangat baik dalam pembelajaran bahasa Indonesia khususnya menulis karangan argumentasi dengan nilai rata-rata kelas yang dicapai adalah 78,81 dan jumlah siswa yang mencapai kriteria ketutansan minimal sebanyak 17 dari 20 siswa. 
Peningkatan Kemampuan Menulis Karangan Argumentasi Dengan Menggunakan Model Think Talk Write (TTW) Siswa Kelas X IPA SMA Pertiwi Ambon

\section{E. DAFTAR PUSTAKA}

Abidin, Y. 2012. Pembelajaran Bahasa Berbasis Pendidikan Karakter. Bandung: Refika Aditama

Aqib, Zainal, dkk. 2008. Penelitian Tindakan Kelas untuk Guru SMP, SMA, SMK. Bandung: Yrama Widya

Tarigan, H.G. 1982. Menulis Sebagai Suatu Keterampilan Berbahasa. Bandung: Angkasa

Wiriaatmadja, R. 2014. Metode Penelitian Tindakan Kelas. Bandung: Remaja Rodsakarya 